\title{
PENGARUH KADAR AIR, DOSIS DAN LAMA PENGENDAPAN KOAGULAN SERBUK BIJI KELOR SEBAGAI ALTERNATIF PENGOLAHAN LIMBAH CAIR INDUSTRI TAHU
}

\author{
Ayu Ridaniati Bangun, Siti Aminah, Rudi Anas Hutahaean, M. Yusuf Ritonga \\ Departemen Teknik Kimia, Fakultas Teknik, Universitas Sumatera Utara, \\ Jalan Almamater Kampus USU Medan 20155, Indonesia \\ e-mail: ayu_080405021@students.usu.ac.id
}

\begin{abstract}
Abstrak
Limbah cair industri tahu mengandung bahan-bahan organik yang sangat tinggi. Senyawa-senyawa organik di dalam limbah cair tersebut berupa protein, karbohidrat, lemak dan minyak. Berdasarkan hasil studi Balai Perindustrian Medan terhadap karakteristik air buangan industri tahu di Medan, diketahui bahwa limbah cair industri tahu rata-rata mengandung BOD (4583 mg/l), COD (7050 mg/l), TSS (4743 mg/l) dan minyak atau lemak (26 $\mathrm{mg} / \mathrm{l}$ ) dengan $\mathrm{pH}$ 6,1. Oleh sebab itu, limbah cair tersebut harus diolah terlebih dahulu sebelum dibuang ke lingkungan untuk mengurangi kandungan pencemar yang menyertai limbah tersebut. Salah satu koagulan alternatif yang dapat digunakan adalah serbuk biji kelor. Penelitian ini menggunakan serbuk biji kelor dengan kadar air $7 \%$. Variasi dosis koagulan yang digunakan 2000, 3000, 4000, $5000 \mathrm{mg} / 200 \mathrm{ml}$ limbah cair tahu, ukuran koagulan 50 dan 70 mesh dengan $\mathrm{pH}$ awal adalah 4. Waktu pengendapan optimum yang diperoleh adalah 60 menit dengan penurunan turbiditas 77,43\%, TSS 90,32 \%, dan COD 63,26\% pada dosis koagulan $5000 \mathrm{mg} / 200 \mathrm{ml}$, dan ukuran partikel koagulan 70 mesh dengan pH akhir adalah 4, sehingga dapat disimpulkan bahwa biji kelor dapat digunakan sebagai koagulan yang efektif karena persentase penurunan yang diperoleh di atas $50 \%$.
\end{abstract}

Kata Kunci : limbah cair industri tahu, biji kelor, turbiditas, TSS, COD

\begin{abstract}
Liquid waste industrial of wheys contain very high organic materials. Organic compounds in the effluent are proteins, carbohydrates, fats and oils. Based on the results of field studies on Industry Hall of liquid waste industrial characteristics of whey in Medan, it is known that liquid waste industrial of wheys contain average BOD (4583 mg/l), COD (7050 mg/l), TSS (4743 $\mathrm{mg} / \mathrm{l})$ and oil or fat $(26 \mathrm{mg} / \mathrm{l})$ at $\mathrm{pH}$ 6.1. Therefore, the whey waste water must be treated before it is discharged into the environment to reduce the contaminants that accompany the waste. One alternative that can be used as a coagulant is moringa seed powder. This study used of moringa seed powder with a water content of $7 \%$. Variations of coagulant dosage which are used 2000, 3000, 4000, $5000 \mathrm{mg} / 200 \mathrm{ml}$ liquid waste industrial of whey, coagulant particle size 50 and 70 mesh with the initial pH about 4 . The optimum deposition time is obtained 60 minutes with $77.43 \%$ reduction in turbidity, TSS $90.32 \%$, and $63.26 \%$ COD in $5000 \mathrm{mg} / 200 \mathrm{ml}$ dosage of coagulant and coagulant particle size of 70 mesh with the final $\mathrm{pH}$ about 4 , it can be concluded that moringa seeds can be used as an effective coagulant because the reductions were obtained over $50 \%$.
\end{abstract}

Keywords : liquid waste industrial of whey, moringa seed powder, turbidity, TSS, COD

\section{Pendahuluan}

Tahu merupakan salah satu jenis makanan sumber protein dengan bahan dasar kacang kedelai yang sangat akrab khususnya bagi masyarakat Indonesia dan bahkan Asia umumnya. Berdasarkan laporan proyek Environmental Management Development in Indonesia atau EMDI [4], pada tahun 1990, jumlah industri tahu di Indonesia tercatat sebanyak 25.870 dan 63 diantaranya merupakan industri skala besar dan menengah, sedangkan sisanya berskala kecil [8].

Limbah tahu adalah limbah yang dihasilkan dalam proses pembuatan tahu. Limbah tersebut berupa limbah padat dan limbah cair. Limbah padat dapat dimanfaatkan untuk makanan ternak, tetapi limbah cair apabila langsung dibuang ke sungai akan menyebabkan tercemarnya sungai tersebut. Oleh sebab itu, limbah cair tahu harus diolah terlebih dahulu sebelum dibuang ke lingkungan untuk mengurangi konsentrasi kandungan pencemar yang menyertai limbah tersebut [12].

Suatu hasil studi tentang karakteristik air buangan industri tahu-tempe di Medan [5], dilaporkan bahwa air buangan industri tahu rata-rata mengandung BOD, COD, TSS dan minyak/ lemak berturut-turut sebesar 4583, 7050, 4743, dan $26 \mathrm{mg} / \mathrm{l}$. Sementara EMDI Bapedal [4] melaporkan kandungan rata-rata BOD, COD dan TSS berturut-turut sebesar 3250, 6520, dan $1500 \mathrm{mg} / \mathrm{l}$. Bila dibandingkan dengan baku mutu limbah cair industri produk makanan dari kedelai menurut kepMenLH No. Kep-51/MENLH/10/1995 tentang Baku Mutu Limbah Cair bagi Kegiatan Industri, kadar maksimum yang diperbolehkan untuk $\mathrm{BOD}_{5}$, COD dan TSS berturut-turut sebesar 50, 100, dan 200 $\mathrm{mg} / \mathrm{l}$, sehingga jelas bahwa limbah cair tahu ini telah melampaui baku mutu yang dipersyaratkan [8]. 
Biji kelor dapat dipergunakan sebagai salah satu koagulan alami alternatif yang tersedia secara lokal. Biji kelor yang dipergunakan dibiarkan sampai matang atau tua dipohon baru dipanen setelah kering dengan kadar air kurang lebih sama dengan $10 \%$. Menurut penelitian dilaporkan bahwa tepung biji kelor adalah bahan alami yang dapat membersihkan limbah cair relatif sama efektifnya bila dilakukan dengan cara pembersihan menggunakan bahan kimia [11].

Oleh karena itu, dengan adanya penelitian ini diharapkan dapat diperoleh bahan koagulan pengolahan limbah cair yang relatif murah sekaligus menambah nilai ekonomisnya.

\section{Teori}

\section{Koagulasi}

Koagulasi merupakan proses yang memanfaatkan ion-ion yang mempunyai muatan berlawanan dengan muatan koloid yang terdapat dalam limbah cair sehingga meniadakan kestabilan ion. Prinsip dasar proses koagulasi adalah terjadinya gaya tarik menarik antara ion-ion negatif di suatu pihak dengan ion-ion positif di pihak lain. Yang bertindak sebagai ion negatif adalah partikel-partikel yang terdiri dari zat-zat organik (partikel koloid), mikoorganisme dan bakteri [3].

\section{Flokulasi}

Flokulasi merupakan kelanjutan dari proses koagulasi, dimana mikroflok hasil koagulasi mulai menggumpalkan partikel-partikel koloid menjadi flokflok besar yang dapat diendapkan dan proses ini dibantu dengan pengadukan lambat. Proses koagulasiflokulasi tidak dapat dipisahkan dalam pengolahan limbah cair industri karena kedua proses ini selalu dilakukan bersama. Mekanisme pembentukan flok-flok dalam proses koagulasi-flokulasi terdiri dari tiga tahap, yaitu tahap destabilisasi partikel-partikel koloid, tahap pembentukan mikrofilik dan tahap pembentukan makrofilik. Tahap pertama dan kedua berlangsung selama proses koagulasi, sedangkan tahap ketiga berlangsung selama proses flokulasi. Pembentukan makrofilik dalam proses flokulasi terjadi karena tumbukan-tumbukan antara partikel koloid [3].

Tahu

Bahan-bahan organik yang terkandung di dalam buangan industri tahu pada umumnya sangat tinggi. Senyawa-senyawa organik di dalam air buangan tersebut dapat berupa protein, karbohidrat, lemak dan minyak. Di antara senyawa-senyawa tersebut, protein dan lemaklah yang jumlahnya paling besar [10] yang mencapai $40 \%$ - $60 \%$ protein, 25 - $50 \%$ karbohidrat, dan $10 \%$ lemak [15]. Semakin lama jumlah dan jenis bahan organik ini semakin banyak, dalam hal ini akan menyulitkan pengelolaan limbah, karena beberapa zat sulit diuraikan oleh mikroorganisme di dalam air limbah tahu tersebut [7].

\section{Biji Kelor}

Tanaman kelor (Moringa oleifera), berasal dari familia Moringaceae merupakan jenis tumbuhan perdu (termasuk ke dalam tumbuhan tingkat tinggi) dengan tinggi batang 7 - 11 meter, berbatang lunak dan rapuh, dengan daun sebesar ujung jari berbentuk bulat telur dan tersusun majemuk [1].

Biji kelor juga berperan sebagai koagulan yang efektif karena adanya zat aktif 4-alfa-4-rhamnosyloxybenzil-isothiocyanate yang terkandung dalam biji kelor. Zat aktif itu mampu mengadsorbsi partikel-partikel air limbah. Dengan pengubahan bentuk menjadi bentuk yang lebih kecil, maka zat aktif dari biji kelor tersebut akan semakin banyak karena luas permukaan biji kelor semakin besar. Apabila kandungan air di dalam biji kelor besar, maka kemampuannya dalam menyerap limbah cair semakin kecil karena zat aktif tersebut tidak berada di permukaan biji kelor tetapi tertutupi oleh air sehingga kelembaban biji kelor harus kecil [13].

\section{Metodologi Penelitian \\ Perlakuan Pengambilan Sampel}

Diambil limbah cair tahu sebanyak 3 liter, lalu limbah cair dimasukkan ke dalam wadah, kemudian limbah cair disimpan pada suhu $4{ }^{\circ} \mathrm{C}$.

\section{Perlakuan Pengambilan Biji Kelor}

Diambil biji kelor yang sudah tua secukupnya dan dikupas kulitnya. Biji kelor yang sudah dikupas kulitnya dihaluskan dengan blender. Serbuk biji kelor diayak dengan ayakan 50 dan 70 mesh, kemudian disimpan di dalam wadah pada suhu ruangan $(28-30$ $\left.{ }^{\circ} \mathrm{C}\right)$.

\section{Perlakuan Biji Kelor untuk Kadar Air $7 \%$ dan Dosis $2000 \mathrm{mg}$}

Serbuk biji kelor ukuran 50 dan 70 mesh dikeringkan di dalam oven pada suhu $>105{ }^{\circ} \mathrm{C}$ selama \pm 2 jam. Serbuk biji kelor ukuran 50 dan 70 mesh ditimbang sebanyak 2105,3 mg dan dimasukkan ke dalam wadah. Kemudian dikeringkan lagi di dalam oven pada suhu > $105{ }^{\circ} \mathrm{C}$ sampai waktu tertentu. Ditimbang hasilnya hingga konstan yaitu $2000 \mathrm{mg}$ sebanyak 3 kali.

\section{Pengaruh Kadar Air, Dosis, dan Lama Pengendaan Koagulan Serbuk Biji Kelor terhadap Persentase Penurunan Turbiditas, TSS dan COD}

Beaker gelas masing-masing diisi dengan sampel limbah cair industri tahu sebanyak $200 \mathrm{ml}$. Diukur pH, turbiditas, TSS, dan COD awal limbah cair industri tahu. Kemudian koagulan (serbuk biji kelor) $7 \%$ ditambahkan ke dalam beaker masing-masing sebanyak 2000, 3000, 4000, dan $5000 \mathrm{mg} / 200 \mathrm{ml}$ limbah cair industri tahu. Sampel kemudian diaduk cepat selama 3 menit (300 rpm) dan diikuti dengan pengadukan lambat selama 12 menit (80 rpm). Setelah pengadukan, diendapkan selama 50, 60 dan 70 menit. Setelah pengendapan, hasil diambil dan dilakukan pengukuran 
$\mathrm{pH}$, Turbiditas, TSS dan COD dari masing-masing sampel, lalu dosis dan waktu optimumnya dipilih.

\section{Pengukuran Turbiditas}

Sampel dimasukkan ke dalam botol turbidimeter dan diusahakan tidak ada gelembung udara. Kemudian botol tersebut ditempatkan pada tempat pengukuran. Dibaca nilai kekeruhan yang muncul pada alat.

Penyisihan turbiditas dapat dihitung dengan persamaan berikut :

Penyisihan Turbiditas $=\frac{(\mathrm{A}-\mathrm{B})}{\mathrm{A}} \times 100 \%$

Keterangan:

$\mathrm{A}=$ Turbiditas awal (FAU)

$\mathrm{B}=$ Turbiditas akhir (FAU)

\section{Pengukuran Total Solid Suspended (TSS)}

Disiapkan kertas saring. Kertas saring dimasukkan ke dalam oven pada suhu $105^{\circ} \mathrm{C}$ selama 1 jam. Kertas saring dimasukkan ke dalam desikator selama 15 hingga 30 menit untuk menetralkan suhunya. Kertas saring ditimbang menggunakan neraca analitik dan dicatat hasilnya. Diletakkan kertas saring pada corong di atas erlenmeyer. Diambil $100 \mathrm{ml}$ sampel limbah cair tahu kemudian disaring. Kertas saring dibilas menggunakan $5 \mathrm{ml}$ aquadest. Kertas saring dan residu dimasukkann ke dalam oven pada suhu $105{ }^{\circ} \mathrm{C}$ selama 1 jam. Kertas saring dan residu ditimbang dan dicatat hasilnya. Diukur kadar TSS nya.

Kadar zat padat tersuspensi dapat dihitung dengan persamaan berikut :

$\operatorname{TSS}(\mathrm{mg} / \mathrm{L})=\frac{(\mathrm{A}-\mathrm{B}) \times 1000}{\mathrm{C}} \ldots \ldots \ldots$

Keterangan:

$\mathrm{A}=$ Berat residu sebelum pemanasan $105^{\circ} \mathrm{C}(\mathrm{mg})$

$\mathrm{B}=$ Berat residu sesudah pemanasan $105^{\circ} \mathrm{C}(\mathrm{mg})$

$\mathrm{C}=$ Volume sampel $(\mathrm{ml})$

\section{Pengukuran Chemical Oxygen Demand (COD)}

\section{Pembuatan Larutan Pereaksi}

a. Pembuatan Standar Primer $\mathrm{K}_{2} \mathrm{CrO}_{7} 0,1 \mathrm{~N}$

Larutkan 4,903 $\mathrm{g} \mathrm{K}_{2} \mathrm{CrO}_{7} \mathrm{AR}$ dalam labu ukur hingga volumenya $1 \mathrm{~L}$ dengan aquadest.

b. Asam Sulfat, AR.

c. Larutan $\mathrm{Ag}_{2} \mathrm{SO}_{4} 1,25 \%$

Dengan hati-hati larutkan $12,5 \mathrm{~g} \mathrm{Ag}_{2} \mathrm{SO}_{4}$ menjadi 1 liter dengan $\mathrm{H}_{2} \mathrm{SO}_{4} 50 \%$ pada saat campuran asam sulfat tersebut masih hangat.

d. Ferro-1 : 10 phenanthicline indikator Larutkan 0,695 gram $\mathrm{FeSO}_{4} \cdot 7 \mathrm{H}_{2} \mathrm{O}$ di dalam 100 $\mathrm{ml}$ aquadest, tambahkan 1,485gr 1:10 phenanthicline mono hydrate, kocok dan biarkan 2 hari agar melarut semua.

e. Ferro sulfat $0,1 \mathrm{~N}$

Larutkan $27,8 \mathrm{~g} \mathrm{FeSO}_{4} .7 \mathrm{H}_{2} \mathrm{O}$ di dalam $\pm 500 \mathrm{ml}$ aquadest, tambahkan $25 \mathrm{ml} \mathrm{H}_{2} \mathrm{SO}_{4}$ pekat, kocok, dinginkan dan tepatkan 1 liter dengan aquadest. Larutan ini harus disimpan dalam botol berwarna dan ditempat gelap. Jika larutan ini disimpan terlalu lama, ada kecenderungan untuk teroksidasi menjadi ferri sulfat. Oleh karena itu setiap melakukan penetapan COD, larutan ini harus distandarisasi dengan $\mathrm{K}_{2} \mathrm{CrO}_{7}$.

\section{Prosedur Analisa COD}

a. Pipet $25 \mathrm{ml} \mathrm{K}_{2} \mathrm{CrO}_{7} 0,1 \mathrm{~N}$ ke dalam labu destilasi $500 \mathrm{ml}$

b. Perlahan-lahan (melalui buret) ditambahkan 30 $\mathrm{ml} \mathrm{H}_{2} \mathrm{SO}_{4}$ pekat sambil digoyang-goyang

c. Pada saat campuran masih agak panas, perlahanlahan melalui pipet berskala ditambahkan sejumlah tertentu contoh (air limbah) sambil terus digoyang hingga warna berubah dari orange kemerahan menjadi orange kehijauan. Perubahan warna diamati dengan membandingkan terhadap blanko

d. Tambahkan sejumlah asam sulfat pekat yang setara dengan volume contoh dikali 1,2

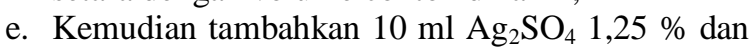
beberapa butir batu reflux dilakukan selama 2 jam (minimum)

f. Dinginkan $\pm 1 / 2$ jam dan bilasi kondensor dengan aquadest. Campurkan pembilas ke dalam labu destilasi, dinginkan dengan air mengalir

g. Sebelum titrasi, tambahkan aquadest hingga volumenya menjadi kira-kira 4 kali volume semula. Tambahkan 5-6 tetes indikator phenanthrolin

h. Titrasi dengan ferro sulfat $0,1 \mathrm{~N}$ hingga warna menjadi cokelat kemerahan (titik akhir). Titik ekuivalen ini cukup tajam, kerjakan titrasi blanko.

Untuk mengukur nilai COD digunakan rumus:

$\operatorname{COD}(\mathrm{mg} / \mathrm{L})=\frac{(\mathrm{a}-\mathrm{b})(\mathrm{c} \times 8000)}{\text { volumecontoh }}=\mathrm{mg} / \mathrm{L}$

Keterangan :

$\mathrm{a}=\mathrm{ml} \mathrm{FeSO}_{4}$ 0,1 $\mathrm{N}$ untuk titrasi blanko

$\mathrm{b}=\mathrm{ml} \mathrm{FeSO}_{4} 0,1 \mathrm{~N}$ untuk titrasi contoh

$\mathrm{c}=$ normalitas $\mathrm{FeSO}_{4}(0,1 \mathrm{~N})$

Hasil

Tabel 1. Data Awal Limbah Cair Industri Tahu

\begin{tabular}{|c|c|c|c|}
\hline No & Parameter & Jumlah & Satuan \\
\hline 1 & Kekeruhan & 350 & FAU \\
\hline 2 & TSS & 3100 & $\mathrm{mg} / \mathrm{l}$ \\
\hline 3 & COD & 6785 & $\mathrm{mg} / \mathrm{l}$ \\
\hline 4 & $\mathrm{pH}$ & 4 & - \\
\hline
\end{tabular}


Pengaruh Dosis Koagulan Serbuk Biji Kelor $7 \%$ dengan Ukuran 50 Mesh terhadap Penurunan Turbiditas Limbah Cair Industri Tahu

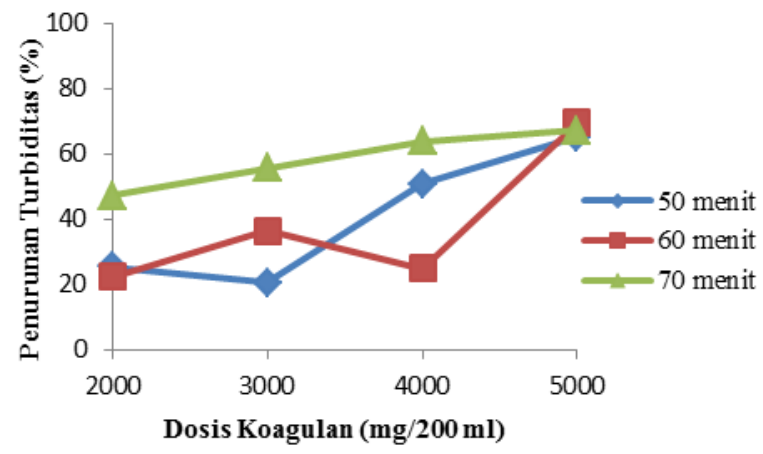

Gambar 1. Hubungan Dosis Koagulan Serbuk Biji Kelor terhadap Penurunan Turbiditas (Kadar $7 \%$, 50 Mesh)

Gambar 1 menunjukkan bahwa serbuk biji kelor dengan kadar air $7 \%$ mampu menurunkan turbiditas limbah cair industri tahu pada berbagai waktu pengendapan dan dosis koagulan. Dari Gambar 1 terlihat adanya penyimpangan pada dosis koagulan $3000 \mathrm{mg} / 200 \mathrm{ml}$ limbah cair industri tahu dengan lama pengendapan 50 menit dan pada dosis koagulan 4000 $\mathrm{mg} / 200 \mathrm{ml}$ limbah cair industri tahu dengan lama pengendapan 60 menit dimana persentase penurunan turbiditas mengalami penurunan menjadi $20,57 \%$ dan $24,86 \%$. Penyimpangan ini mungkin disebabkan karena pada waktu tersebut tidak semua koagulan yang terkoagulasi dan terflokulasi dengan sempurna.

Penurunan turbiditas optimum diperoleh pada dosis koagulan serbuk biji kelor $5000 \mathrm{mg} / 200 \mathrm{ml}$ limbah cair industri tahu pada waktu pengendapan 60 menit sebesar $69,43 \%$, dengan ukuran partikel 50 mesh dan $\mathrm{pH} 4$ limbah cair industri tahu. Nilai $\mathrm{pH}$ limbah cair industri tahu tidak mengalami perubahan. Hal ini sesuai dengan hasil percobaan yang dilakukan oleh [9] dalam [6], dimana proses koagulasi menggunakan biji kelor memberikan pengaruh kecil terhadap derajat keasaman dan konduktifitas.

Berdasarkan teori, dosis koagulan sangat berpengaruh terhadap penyisihan turbiditas limbah cair industri tahu karena dengan memberikan dosis yang tepat maka penyisihan turbiditas sampel akan semakin signifikan. Menurut [16] suatu koagulan dikatakan efektif, apabila mampu mengurangi nilai turbiditas sebesar $50 \%$ sehingga koagulan serbuk biji kelor ini merupakan koagulan yang efektif untuk menurunkan turbiditas limbah cair industri tahu.
Pengaruh Dosis Koagulan Serbuk Biji Kelor $7 \%$ dengan Ukuran 70 Mesh terhadap Penurunan Turbiditas Limbah Cair Industri Tahu

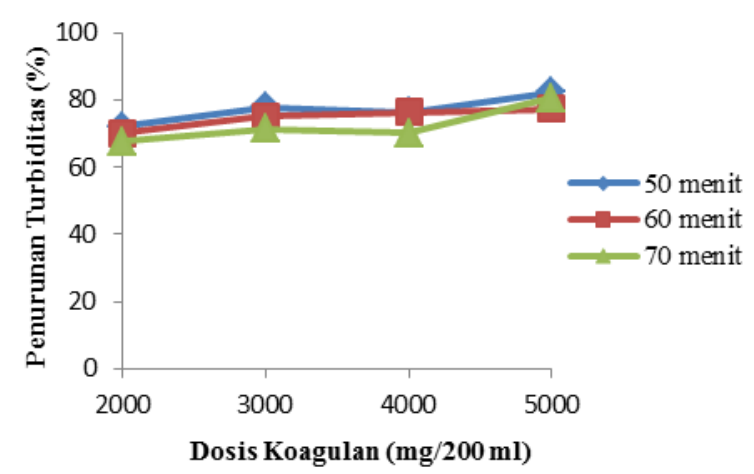

Gambar 2. Hubungan Dosis Koagulan Serbuk Biji Kelor terhadap Penurunan Turbiditas (Kadar $7 \%$, 70 Mesh)

Gambar 2 menunjukkan bahwa serbuk biji kelor dengan kadar air $7 \%$ mampu menurunkan turbiditas limbah cair industri tahu pada berbagai waktu pengendapan dan dosis koagulan. Dari Gambar 2 terlihat adanya penyimpangan pada dosis koagulan $4000 \mathrm{mg} / 200 \mathrm{ml}$ limbah cair industri tahu dengan lama pengendapan 50 menit dan pada dosis koagulan 4000 $\mathrm{mg} / 200 \mathrm{ml}$ limbah cair industri tahu dengan lama pengendapan 70 menit dimana persentase penurunan turbiditas mengalami penurunan menjadi 76,29\% dan $70,29 \%$. Penyimpangan ini mungkin disebabkan karena pada waktu tersebut tidak semua koagulan yang terkoagulasi dan terflokulasi dengan sempurna.

Penurunan turbiditas optimum diperoleh pada dosis koagulan serbuk biji kelor $5000 \mathrm{mg} / 200 \mathrm{ml}$ limbah cair industri tahu pada waktu pengendapan 50 menit sebesar 82,29\%, dengan ukuran partikel 70 mesh dan $\mathrm{pH} 4$ limbah cair industri tahu. Nilai $\mathrm{pH}$ limbah cair industri tahu tidak mengalami perubahan. Hal ini sesuai dengan hasil percobaan yang dilakukan oleh [9] dalam Chandra [6], dimana proses koagulasi menggunakan biji kelor memberikan pengaruh kecil terhadap derajat keasaman dan konduktifitas.

Berdasarkan teori, dosis koagulan sangat berpengaruh terhadap penyisihan turbiditas limbah cair industri tahu karena dengan memberikan dosis yang tepat maka penyisihan turbiditas sampel akan semakin signifikan. Menurut [16] suatu koagulan dikatakan efektif, apabila mampu mengurangi nilai turbiditas sebesar $50 \%$ sehingga koagulan serbuk biji kelor ini merupakan koagulan yang efektif untuk menurunkan turbiditas limbah cair industri tahu. 
Pengaruh Dosis Koagulan Serbuk Biji Kelor $7 \%$ dengan Ukuran 50 Mesh terhadap Persentase Penurunan TSS Limbah Cair Industri Tahu

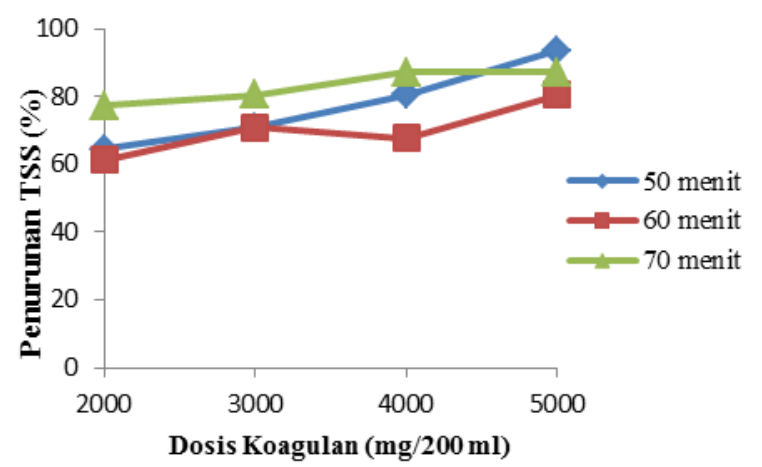

Gambar 3. Hubungan Dosis Koagulan Serbuk Biji Kelor terhadap Penurunan TSS (Kadar $7 \%, 50$ Mesh)

Gambar 3 menunjukkan bahwa penurunan TSS tertinggi diperoleh pada dosis koagulan serbuk biji kelor $7 \%$ sebanyak $5000 \mathrm{mg} / 200 \mathrm{ml}$ limbah cair industri tahu dengan waktu pengendapan 50 menit dengan penurunan sebesar 93,55\% dengan ukuran 50 mesh.

Dari Gambar 3 terlihat adanya penyimpangan pada dosis koagulan $4000 \mathrm{mg} / 200 \mathrm{ml} \mathrm{limbah}$ cair industri tahu dengan lama pengendapan 60 menit dimana persentase penurunan TSS mengalami penurunan menjadi 67,74 \%. Penyimpangan ini mungkin disebabkan karena pada waktu tersebut tidak semua partikel koagulan bereaksi membentuk flok-flok dalam limbah cair industri tahu.

Berdasarkan teori yang ada, semakin besar konsentrasi koagulan yang digunakan maka semakin besar juga jumlah partikel bahan tersuspensi (TSS) yang tersisihkan. Hal ini sesuai dengan hasil penelitian yang dilakukan oleh [14] bahwa penghilangan flok berupa turbiditas dan TSS dari media cair bergantung pada jenis dan jumlah suspensi koloid, pH, komposisi kimia cairan dan jenis koagulan.

Nilai $\mathrm{pH}$ limbah cair industri tahu tidak mengalami perubahan. Hal ini sesuai dengan hasil percobaan yang dilakukan oleh [9] dalam [6], dimana proses koagulasi menggunakan biji kelor memberikan pengaruh kecil terhadap derajat keasaman dan konduktifitas.
Pengaruh Dosis Koagulan Serbuk Biji Kelor $7 \%$ dengan Ukuran 70 Mesh terhadap Persentase Penurunan TSS Limbah Cair Industri Tahu

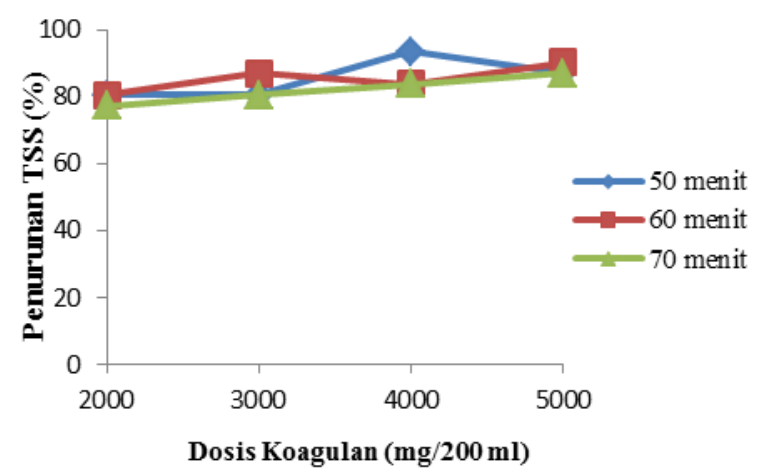

Gambar 4. Hubungan Dosis Koagulan Serbuk Biji Kelor terhadap Penurunan TSS (Kadar $7 \%, 70$ Mesh)

Gambar 4 menunjukkan bahwa penurunan TSS tertinggi diperoleh pada dosis koagulan serbuk biji kelor $7 \%$ sebanyak $4000 \mathrm{mg} / 200 \mathrm{ml}$ limbah cair industri tahu dengan waktu pengendapan 50 menit dengan penurunan sebesar $93,55 \%$ dengan ukuran 70 mesh.

Dari Gambar 4 terlihat adanya penyimpangan pada dosis koagulan $5000 \mathrm{mg} / 200 \mathrm{ml} \mathrm{limbah}$ cair industri tahu dengan lama pengendapan 50 menit dan pada dosis koagulan $4000 \mathrm{mg} / 200 \mathrm{ml} \mathrm{limbah}$ cair industri tahu dengan lama pengendapan 60 menit dimana persentase penurunan TSS mengalami penurunan menjadi $87,1 \%$ dan $83,87 \%$. Penyimpangan ini mungkin disebabkan karena pada waktu tersebut tidak semua partikel koagulan bereaksi membentuk flok-flok dalam limbah cair industri tahu.

Berdasarkan teori yang ada, semakin besar konsentrasi koagulan yang digunakan maka semakin besar juga jumlah partikel bahan tersuspensi (TSS) yang tersisihkan. Hal ini sesuai dengan hasil penelitian yang dilakukan oleh [14] bahwa penghilangan flok berupa turbiditas dan TSS dari media cair bergantung pada jenis dan jumlah suspensi koloid, pH, komposisi kimia cairan dan jenis koagulan.

Nilai pH limbah cair industri tahu tidak mengalami perubahan. Hal ini sesuai dengan hasil percobaan yang dilakukan oleh [9] dalam [6], dimana proses koagulasi menggunakan biji kelor memberikan pengaruh kecil terhadap derajat keasaman dan konduktifitas. 
Pengaruh Dosis Koagulan Serbuk Biji Kelor $7 \%$ dengan Ukuran 50 mesh terhadap Persentase Penurunan COD Limbah Cair Industri Tahu

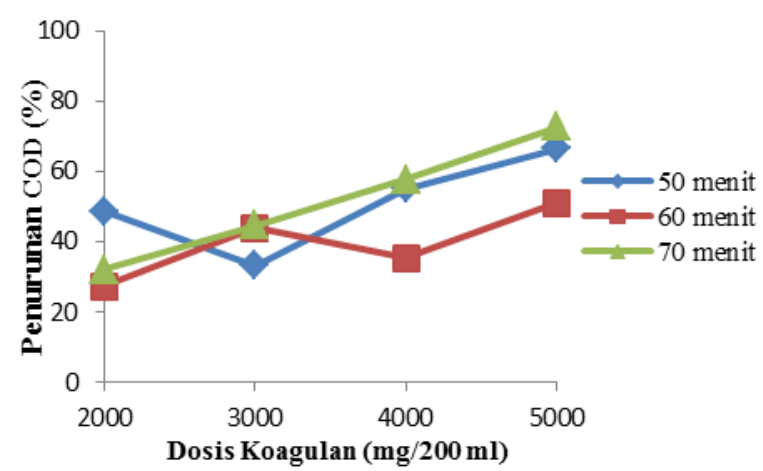

Gambar 5. Hubungan Dosis Koagulan Serbuk Biji Kelor terhadap Persentase Penurunan COD (Kadar $7 \%, 50$ Mesh)

Dari Gambar 5 dapat dilihat penurunan optimum COD limbah cair industri tahu dengan koagulan serbuk biji kelor $7 \%$ berukuran 50 mesh diperoleh pada dosis $5000 \mathrm{mg} / 200 \mathrm{ml}$ dengan waktu pengendapan 70 menit mampu menurunkan COD sebesar 72,7 \%. Hasil yang diperoleh jauh diatas baku mutu limbah cair yang ditetapkan kep-51/MENLH/10/1995, dimana baku mutu COD limbah cair yang dapat dibuang ke lingkungan adalah sebesar $100 \mathrm{mg} / \mathrm{L}$.

Dari Gambar 5 terlihat adanya penyimpangan pada dosis koagulan $3000 \mathrm{mg} / 200 \mathrm{ml}$ limbah cair industri tahu dengan lama pengendapan 50 menit dan pada dosis koagulan $4000 \mathrm{mg} / 200 \mathrm{ml} \mathrm{limbah}$ cair industri tahu dengan lama pengendapan 60 menit dimana persentase penurunan COD mengalami penurunan menjadi $33,22 \%$ dan $35,5 \%$. Penyimpangan ini mungkin disebabkan karena pada waktu tersebut tidak semua partikel koagulan bereaksi membentuk flok-flok dalam limbah cair industri tahu.

COD adalah banyaknya oksigen yang dibutuhkan untuk mengoksidasi secara kimia bahan organik di dalam air. COD yang diperoleh dari proses koagulasi tidak dapat memenuhi baku mutu dikarenakan banyaknya kandungan zat-zat organik dan anorganik yang terkandung di dalam limbah cair industri tahu tersebut. Untuk dapat menyisihkan kadar COD yang tinggi pada limbah cair, diperlukan pengolahan lebih lanjut. Di dalam proses pengolahan limbah cair, koagulasi merupakan bagian dari Primary Treatment (pengolahan tahap pertama) yang memiliki tujuan untuk menghilangkan padatan tersuspensi didalam air limbah. Sedangkan tahapan selanjuntya yaitu Secondary Treatment (pengolahan tahap kedua) bertujuan menghilangkan material organik pada air limbah [2]. Tahap ini dapat memberikan angka penurunan COD yang lebih besar, dengan hasil yang dicapai dapat disesuaikan dengan baku mutu COD ditetapkan kep-51/MENLH/10/1995 sehingga aman bagi lingkungan sekitar.

Nilai $\mathrm{pH}$ limbah cair industri tahu tidak mengalami perubahan. Hal ini sesuai dengan hasil percobaan yang dilakukan oleh [9] dalam Chandra [6], dimana proses koagulasi menggunakan biji kelor memberikan pengaruh kecil terhadap derajat keasaman dan konduktifitas.

Pengaruh Dosis Koagulan Serbuk Biji Kelor $7 \%$ dengan Ukuran 70 mesh terhadap Persentase Penurunan COD Limbah Cair Industri Tahu

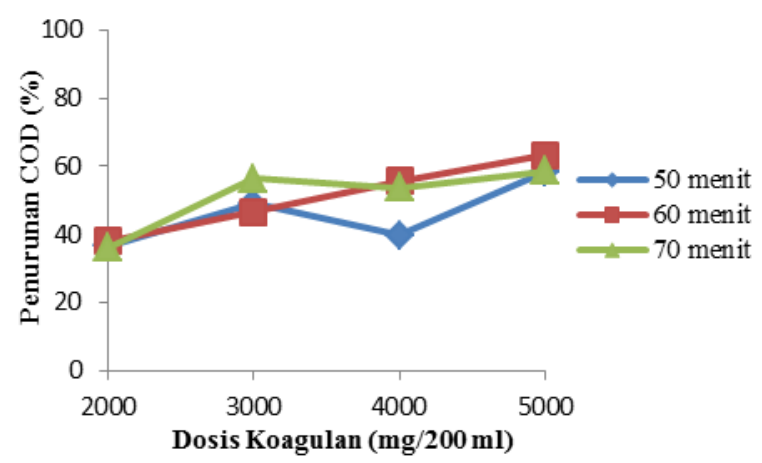

Gambar 6. Hubungan Dosis Koagulan Serbuk Biji Kelor terhadap Persentase Penurunan COD (Kadar $7 \%, 70$ Mesh)

Dari Gambar 6 dapat dilihat penurunan optimum COD limbah cair industri tahu dengan koagulan serbuk biji kelor $7 \%$ berukuran 70 mesh diperoleh pada dosis $5000 \mathrm{mg} / 200 \mathrm{ml}$ dengan waktu pengendapan 60 menit mampu menurunkan COD sebesar 63,26 \%. Hasil yang diperoleh jauh diatas baku mutu limbah cair yang ditetapkan kep-51/MENLH/10/1995, dimana baku mutu COD limbah cair yang dapat dibuang ke lingkungan adalah sebesar $100 \mathrm{mg} / \mathrm{L}$.

Dari Gambar 6 terlihat adanya penyimpangan pada dosis koagulan $4000 \mathrm{mg} / 200 \mathrm{ml} \mathrm{limbah}$ cair industri tahu dengan lama pengendapan 50 menit dan pada dosis koagulan $4000 \mathrm{mg} / 200 \mathrm{ml}$ limbah cair industri tahu dengan lama pengendapan 70 menit dimana persentase penurunan COD mengalami penurunan menjadi 39,72 \% dan 53,65 \%. Penyimpangan ini mungkin disebabkan karena pada waktu tersebut tidak semua partikel koagulan bereaksi membentuk flok-flok dalam limbah cair industri tahu.

COD adalah banyaknya oksigen yang dibutuhkan untuk mengoksidasi secara kimia bahan organik di dalam air. COD yang diperoleh dari proses koagulasi tidak dapat memenuhi baku mutu dikarenakan banyaknya kandungan zat-zat organik dan anorganik yang terkandung di dalam limbah cair industri tahu tersebut. Untuk dapat menyisihkan kadar COD yang tinggi pada limbah cair, diperlukan pengolahan lebih lanjut. Di dalam proses pengolahan limbah cair, koagulasi merupakan bagian dari Primary Treatment 
(pengolahan tahap pertama) yang memiliki tujuan untuk menghilangkan padatan tersuspensi didalam air limbah. Sedangkan tahapan selanjuntya yaitu Secondary Treatment (pengolahan tahap kedua) bertujuan menghilangkan material organik pada air limbah [2]. Tahap ini dapat memberikan angka penurunan COD yang lebih besar, dengan hasil yang dicapai dapat disesuaikan dengan baku mutu COD ditetapkan kep-51/MENLH/10/1995 sehingga aman bagi lingkungan sekitar.

Nilai $\mathrm{pH}$ limbah cair industri tahu tidak mengalami perubahan. Hal ini sesuai dengan hasil percobaan yang dilakukan oleh [9] dalam [6], dimana proses koagulasi menggunakan biji kelor memberikan pengaruh kecil terhadap derajat keasaman dan konduktifitas.

\section{Kesimpulan}

Semakin rendah kadar air yang terdapat di dalam biji kelor, maka semakin besar kemampuannya dalam menurunkan turbiditas, TSS, dan COD dalam limbah cair industri tahu. Semakin kecil (halus) ukuran serbuk biji kelor dan semakin banyak dosisnya, maka penurunan turbiditas, TSS, dan COD juga semakin besar. Penambahan koagulan tidak mempengaruhi nilai $\mathrm{pH}$ limbah cair industri tahu. Lama pengendapan optimum adalah 60 menit dengan penurunan turbiditas $77,43 \%$, TSS $90,32 \%$ dan COD $63,26 \%$ pada dosis koagulan $5000 \mathrm{mg} / \mathrm{L}$, kadar air $7 \%$, pH akhir limbah cair industri tahu 4 dan ukuran partikel koagulan 70 mesh. Terjadinya penyimpangan hasil penelitian yang diperoleh mungkin disebabkan karena tidak semua koagulan yang terkoagulasi dan terflokulasi secara sempurna. Biji kelor merupakan koagulan yang efektif untuk limbah cair industri tahu, ini terlihat dari penurunan kadar turbiditas, TSS, dan COD optimum yang diperoleh melebihi $50 \%$.

\section{Daftar Pustaka}

[1] Adieska, Penelitian Koagulan Biji Kelor pada Limbah Cair Industri, http://adieska.net, 2010.

[2] Aimyaya, Tahapan Pengolahan Limbah Cair, http://aimyaya.blogspot.com, 2008.

[3] Armedi, J., Penyisihan BOD, COD dan TSS Limbah Cair Tahu dengan Kombinasi Koagulasi-Flokulasi dan Ultrafiltrasi, Universtias Riau, Pekanbaru, 2010.

[4] Bapedal, Environmental Management Development in Indonesia, BAPEDAL, Jakarta, 1994.

[5] Bappeda Medan, Penelitian Pencemaran Air Limbah di Sentra industri Kecil Tahul Tempe di Kecamatan Medan Tuntungan Kotamadya Dati II Medan, Bapedda TK II Medan, 1993.

[6] Chandra, A., Penentuan Dosis Optimum Koagulan Ferro Sulfat-Kapur Flokulan Chemifloc dan Besfloc, serta Bioflokulan Moringa Oleifera dalam Pengolahan Limbah Cair Pabrik Tekstil, Laporan Penelitian Jurusan Teknik Kimia, Universitas Parahyangan, Bandung, 1998.

[7] Chondro, A., Studi Komparasi Efektivitas Pengolahan Limbah Cair Industri Tahu Dengan Media Pasir Antara Down Flow Dan Up Flow Untuk Mengurangi Kadar Bod, Universitas Jenderal Sudirman, Purwokerto, 2010.

[8] Husin, A., Pengolahan Limbah Cair Industri Tahu dengan Biofiltrasi Anaerob dalam Reaktor Fixed-Bed, Departemen Teknik Kimia, Universitas Sumatera Utara, Medan, 2008.

[9] Ndabigengesere, A., Narasiah, K. S. dan Talbot B. G., Active Agents and Mechanism of Coagulation of Turbid Water using Moringa Oleifera, Water Research, New York, 1995.

[10] Nurhasan dan Pramudyanto, B. B., Penanganan Air Limbah Tahu, Yayasan Bina Karya Lestari, Jakarta, 1991.

[11] Nurhidayat, Biji Kelor Moringa oleifera, http://nurhidayat.lecture.ub.ac.id, 2010.

[12]Nurika, I., Pemanfaatan Biji Asam Jawa (Tamarindus indica) sebagai Koagulan pada Proses Koagulasi Limbah Cair Tahu, Fakultas Teknologi Pertanian, Universitas Brawijaya, Malang, 2007.

[13]Ritwan, Pemanfaatan Biji Kelor (Moringa Oleifera Lamk) dalam Pengolahan Limbah dan Air Baku Baik Skala Kecil, Sedang dan Besar, http://lib.uin-malang.ac.id, 2004.

[14] Rossi, M. E. dan Ward, N. I., The Influence of Chemical Treatment of Metal Composition of Raw Water, Proc. Int. Conf. on Heavy Metals in the Environ, New York, 1993.

[15] Sugiharto, Dasar-dasar Pengolahan Air Limbah, Universitas Indonesia, Jakarta, 1994.

[16] Wiley J., Principles of Industrial Waste Treatment, John Wiley \& Sons Inc, New York, 1955. 